\title{
Metadiscourse as a Way of Achieving Persuasion in Literary Criticism Texts
}

\author{
Dunya AlJazrawi ${ }^{a}$ \\ d.abdo@ku.edu.bh \\ Kingdom University, Bahrain \\ Zeena AlJazrawi ${ }^{b}$ \\ z.abdo@ku.edu.bh \\ Kingdom University, Bahrain
}

\begin{abstract}
This study aims at examining the use of metadiscourse markers in literary criticism texts to identify the role of the reader and how these markers are used to produce more persuasive essays. The data of 72,727 words from 17 texts were written by three well-known authors, namely, T.S. Eliot, Virginia Woolf and Stanley Fish. Hyland's (2005) model of interpersonal metadiscourse markers was used to analyze the data. The analysis revealed that metadiscourse markers are used by literary critics to create coherent and persuasive texts. It was found out that the theory of criticism adopted by the literary critics does not affect the use of metadiscourse markers only maybe in terms of relying more on logos, ethos or pathos. The results of this study comply with those of previous research showing that metadiscourse markers are frequently used in literary criticism texts. This study will contribute to both the literary genre and the genre of critical essays by identifying the linguistic features to be used to produce more effective and convincing literary criticism texts. It will also help future critics to write more persuasive texts by highlighting the means that enable them to influence their readers and to produce more coherent and convincing texts.
\end{abstract}

Keywords: metadiscourse; persuasion; literary criticism; essays; critical theory

\section{INTRODUCTION}

The main point in almost all approaches to literary criticism has to do with the issue of meaning. The meaning of text in each critical theory is connected and can be interpreted with reference to a particular internal or external factor. Theories of criticism, for example the historical approach that focused on external facts such as historical and biological information, literary and philosophical movements and social context that were popular during the time the text was created, do not place their attention on the features of the text (Baktir, 2018, p. 98).

Other theories like Formalism, New Criticism and Structuralism accused the historical approach of being subjective, because it pays no attention to the features of a text, namely, the textual, formal and literary (Baktir, 2018, p. 98). The other theories asserted that the emphasis should be given on the internal features of the text and no attention should be given to the external features of the text. Thus, in order to interpret a literary work, the new critics focused on the text itself rather than the life of the author or the state of the age during which the author lived (Bressler, 2002).

The reader-response theory considers the meaning in the text to be the result of interaction between the reader, the text and the author. This theory focuses on matters such as the attitude of the author towards the reader, types of readers, the role that the readers play in the determination of meaning and the condition of a literary text (Baktir, 2018, p. 97).

${ }^{a}$ Main author

${ }^{b}$ Corresponding author 
It is worth mentioning that the recognition of the role of the reader or audience of a particular literary work goes back to classical times. Plato recognized the effect that poetry has on the passion and morality of people, and Aristotle in his popular definition of tragedy, considered the audience response an important component. In addition, to many classical and medieval writers, literature is a branch of rhetoric, which is the art of persuasive speaking or writing (Habib, 2005, p. 719). Some of the theories of romanticism emphasized the effect that poetry has on the reader. The subjective response of the reader to literature and art was also emphasized by different theories of the late nineteenth century, such as symbolism and impressionism. Feminism and Marxism are also among the theories that recognized that literary works are always intended to influence certain kinds of audience.

Theories of the nineteenth century such as the subjectivist theories and theories that set literature into a historical framework resulted in the appearance of different kinds of formalism including new criticism. The formalists no longer wanted the emphasis in literature to be on the reader's subjective reactions, nor on the connectivity of the text to its circumstances, but rather on the literary text itself (Habib, 2005, p. 719). To the formalists, the study of literature is an objective activity which aims at studying the structure of the literary text and to identify its literary qualities. This emphasis on formalism and objectivism resulted in the emergence of the reader-response theory which aimed at reviving the tradition that recognized the importance of the role of the reader or audience in the structure of a certain literary or rhetorical situation (Habib, 2005, pp. 719-720).

Thus, it is evident that the role of the reader or audience has been viewed differently in the various theories of criticism. While some theories emphasized the important role of the reader, others have lessened the importance of that role. The literature has paid no attention to the role of metadiscourse markers in literary criticism texts. Previous research tackled literary criticism from a theoretical rather than a practical point of view (Harris, 1996). Even the studies that analyzed literary criticism texts were not concerned with identifying the linguistic features of such texts, for example, Abdulmughni (2019) analyzed literary criticism in order to show the differences between stylistics, literary criticism, linguistics and discourse analysis. Another study attempted to show how academic discourse writers communicate with their readers by different language means, such as hedges (Malaskova, 2014). Stern (1989)'s study concluded that literary criticism constitutes a means of knowing more about the consumer behavior and it provides a general review of literary criticism. Thus, the present study aims to discuss how metadiscourse markers contribute to produce coherent and persuasive literary criticism texts. Consequently, this study has set itself the task of examining the role of the reader and the use of metadiscourse markers in literary criticism texts as a means of achieving persuasion. This is achieved through analyzing critical texts that belong to three critics who adopt different views concerning the role of the reader and to determine whether their different views are reflected in their writings. This study focuses on texts written by T.S Eliot, who is considered as the most influential modernist both in his poetry and literary criticism; Virginia Woolf, who is considered as the pioneer of the feminist literary criticism (Habib, 2005, p. 681); and Stanley Fish, who is considered as one of the leading members of the reader-response theory. In other words, the present study tries to find an answer to the question 'To what extent the authors' view of the role of the reader reflected in their writings of literary criticism'. The study also aims at identifying the effect of metadiscourse markers in producing more persuasive critical essays, since one of the means of achieving persuasion is through the use of such markers (Hyland, 2005). This study will contribute to both the literary genre and the genre of critical essays in identifying the features that help to produce more convincing and coherent texts, hence achieving maximum effect on readers. 


\section{QUESTIONS OF THE STUDY}

The present study tries to find answers to the following questions:

1. What are the types of metadiscourse markers used in the literary critical essays?

2. What is the frequency of each type of markers used by the writers?

3. How do literary critics manage to make their essays persuasive?

4. How are the results of this study related to those of other studies which involved literary and other texts?

5. What is the effect of the theory of criticism that the literary critic adopts on his/her use of metadiscourse markers?

\section{LITERATURE REVIEW}

\section{CRITICAL THEORIES IN LITERARY STUDIES}

The word criticism has been derived from a Greek word which means judgment, and consequently, it refers to an exercise in judgment to identify the weak and strong points of a literary work and to evaluate its artistic worthiness. According to Beckson and Ganze (1989), literary criticism involves evaluating literary works including their classification in terms of genre, structure and value.

Before the twentieth century, investigating the nature and value of literary works started with Plato and Aristotle and continued by Sir Philip Sidney, John Dryden, Samuel Johnson, William Wordsworth, Samuel Taylor Coleridge, and Mathew Arnold, However, such investigations concentrated mainly on the evaluation of literary works rather than on interpretation (Griffith, 2002).

In the middle of the twentieth century, a new method of literary criticism which involved evaluating and interpreting literary texts started to gain attention. This method focused on examining a text closely and paying less attention to the circumstances, whether historical or biographical, in which literary works were produced (Makaryk, 1993). This movement was referred to as new criticism by Ransom (1941) who called the new American formalists as new critics in his book "The New Criticism". Prior to new criticism, literary texts were evaluated in terms of other factors connected with the text in order to identify the intended meaning of the author in the text. Thus, the author's life, his observations, his life circumstances, the political events and others were taken into consideration rather than the text itself. In other words, using Eagleton's (2001, p. 35) words "the biographical-historical criticism seemed to examine the text's biographical-historical context instead of examining the text". Consequently, the Spirit of Modernism of the new critics was reflected in their intension to avoid criticism that was based on impression, which involved judging a literary text depending on the personality and past experience of the author (Lynn, 1998) and the social and historical approach to criticism. The new critics believed that criticism should involve studying the text itself through studying its formal aspects, such as rhythm, meter, theme, imagery and metaphor (Eagleton, 2001, p. 41).

The most influential among all the modernists is T.S. Eliot (1888-1956). Another leading modernist writer is Virginia Woolf (1882-1941) who is considered as a pioneer of the feminist literary criticism (Habib, 2005, p. 681). Thus, Woolf's literary criticism can be viewed from two perspectives, namely, modernism and feminism (Habib, 2005, p. 682). Woolf realized that there are particular strategies that are used by the authors of literary texts for the purpose of achieving certain effects in their readers to direct their reactions (Habib, 2005, p. 720). Stanley Fish is one of the influential supporters of the reader-response theory which emerged as a result of the emphasis on formalism and objectivism. In his early work, Fish focused on what readers 
experience in relation to literary texts. In his essay, "Interpreting the Variorum", he first presented the concept of interpretive communities which was later discussed more in his book Is There a Text in this Class? The Authority of Interpretive Communities. He believes that a formalist analysis will not take into consideration the reader's experience of the text. Moreover, it considers the text as an entity by itself and does not take into account the activities of the reader (Habib, 2005, p. 745). According to Fish, what creates meaning is the experience of the reader and that meaning is determined by the reader's main goal (Habib, 2005:745). Thus, the meaning of a text, as Fish believes, is created within the reader's experience rather than being contained in the text itself.

\section{PERSUASION}

The idea of persuading others has become popular since the publication of Dale Carnegie of his book How to Win Friends and Influence People in the 1930s (Dainton, 2005, p. 103). Simons (1976, as cited in Dainton, 2005, p. 104) defines persuasion as "human communication that is designed to influence others by modifying their beliefs, values, or attitudes". According to O'keefe (1999 as cited in Dainton, 2005, p. 104), for something to be persuasive, certain requirements must be fulfilled concerning the sender, the means and the recipient, the first of which is that persuasion incorporates a goal and a desire by the sender to accomplish that goal. The second requirement is that the means by which this goal is to be achieved is communication, and the third is that the recipient of the message must willingly comply with the message without being forced. Consequently, persuasion does not happen by chance nor does it involve force or threats.

Aristotle (as cited in Garsten, 2006, p. 131, and in Larson, 2010, p. 20) believes that persuasion depends on three types of artistic and inartistic proof, i.e., logos, pathos and ethos. When persuaders use logical or rational appeals (logos), persuasion is achieved through accepting an argument. In the affective appeals (pathos), persuasion is achieved through the movement of emotions. In the credibility appeals (ethos), persuasion is achieved through trusting the judgement and goodwill of the speaker (Larson, 2010, p. 20).

Persuasion can be achieved through the use of different strategies and devices. One of those strategies, according to Hyland (2005, p. 63), is metadiscourse. He argues that metadiscourse supports the three appeals of persuasion, namely, the rational (logos), affective (pathos) and credible (ethos), which have been, according to him, a feature of persuasive discourse since the ancient Greece time (Hyland, 2005, p. 63). Through the analysis of company annual reports, Hyland (2005) found that the metadiscourse markers: transition, frame markers, endophoric markers and code glosses are the markers of the rational appeal; the metadiscourse markers: engagement markers, attitude markers, hedges and pronoun references as the markers of the affective appeal; and finally, the metadiscourse markers: hedges, boosters, engagement markers and evidentials are the markers of the credibility appeal.

\section{METHODOLOGY}

\section{MODEL OF ANALYSIS}

The present study will adopt Hyland's (2005) model of metadiscourse to analyze persuasion in literary criticism texts. This model does not separate the textual and the interpersonal functions, and its links between text and context. The interaction between the addresser and addressees is achieved through social and communicative engagement. In this model, the knowledge, experiences and needs of the addresser are taken into consideration, which indicates that the addresser understands the audience and their expectations (Hyland, 2005, p. 14). 
Thus, the emphasis is not on the organization of the text, but on the relationship between writers and readers. Through their writings, writers aim at negotiating some scenarios and influencing their readers, which fall within the scope of the present study of persuasion in literary criticism.

\section{HYLAND'S (2005) MODEL OF METADISCOURSE}

The main idea involved in metadiscourse is that communication does not involve only on exchanging information, but it also involves the personalities, attitudes and assumptions of the participants. According to Crismore et al. (1993, p. 40), metadiscourse assists readers and listeners to arrange, interpret and assess the given information. There are two approaches to metadiscourse namely the "integrative approach" and the "non-integrative approach" (Mauranen, 1993). In the first approach to metadiscourse, the focus is on the relationship between the addresser and the addressee and not on the text (Williams, 1981; Vande Kopple 1985, 1988; Crismore, 1989; Mao, 1993; Hyland, 1998), whereas in the second approach the focus is on the text (Schiffrin, 1980; Telenius, 1994; Bäcklund, 1998; Bunton, 1999, Dahl, 2004, and for more information on such studies (cf. Adel 2006, pp. 171-178).

In Hyland's model of metadiscourse (2005), the markers of are divided into two main categories, namely, the "interactive" and "interactional". The function of interactive metadiscourse is to guide the addressee throughout the text (Hyland, 2005, p. 49). It reflects the writer's awareness of the presence of the audience and his or her intention to realize their "interests", "rhetorical expectations" and "processing abilities". It also reflects the addressees' expectation of the argument to follow standard patterns so that the text is recognized as being appropriate and convincing by them (Hyland, 2005, p. 54). Interactive markers of metadiscourse include: "transitions", "frame markers", "evidentials", "endophoric markers" and "code glosses". The interactional metadiscourse has to do with addressers direct interaction being the writer's personality or 'voice'. The addresses are being involved in the text through the addresser's arguments. Through these arguments, addressers manage to influence their addressees, draw their attention to something and direct them to interpretations (Hyland, 2005, p. 52). Hyland considers interactional markers to be evaluative and engaging, because they bring in the addressees in the argument. This category of metadiscourse includes "hedges", "boosters", "engagement markers", "attitude markers" and "self-mention". Table 1 below displays Hyland's (2005) categorization of metadiscourse markers.

TABLE 1. Hyland's (2005) classification of metadiscourse markers

\begin{tabular}{|c|c|c|}
\hline \multirow{2}{*}{$\begin{array}{l}\text { Category } \\
\text { Interactive }\end{array}$} & \multirow{2}{*}{\multicolumn{2}{|c|}{$\begin{array}{l}\text { Examples } \\
\text { Help to guide the reader through Resources the text }\end{array}$}} \\
\hline & & \\
\hline Transitions & express relations between main clauses & in addition; but; thus; and \\
\hline Frame markers & refer to discourse acts, sequences or stages & finally; to conclude; my purpose is \\
\hline Endophoric markers & refer to information in other parts of the text & noted above; see Fig; in section 2 \\
\hline Evidential & refer to information from other texts & according to $X ; Z$ states \\
\hline Code glosses & elaborate prepositional meanings & $\begin{array}{l}\text { namely; e.g.; such as; in other } \\
\text { words }\end{array}$ \\
\hline Interactional & \multicolumn{2}{|l|}{ Involve the reader in the text } \\
\hline Hedges & withhold commitment and open dialogue & might; perhaps; possible; about \\
\hline Boosters & emphasize certainty or close dialogue & in fact; definitely; it is clear that \\
\hline Attitude markers & express writer's attitude to proposition & $\begin{array}{l}\text { unfortunately; I agree; } \\
\text { surprisingly }\end{array}$ \\
\hline Self mentions & explicit reference to author(s) & $I ;$ we; my; me; our \\
\hline Engagement markers & explicitly build relationship with reader & consider; note; you can see that \\
\hline
\end{tabular}




\section{DATA ANALYSIS}

MATERIALS

This research involves the analysis of data from three critics who represent different critical approaches, namely, T.S. Eliot as a representative of formalism, Virginia Woolf as a representative of the feminist criticism and Stanley Fish as a representative of the readerresponse theory. The data consists of critical essays written by Eliot, Woolf and Fish. Eliot's data consists of ten essays whose numbers of words range between 1570-4803 words with a total of 24, 613. Woolf's data consists of 6 essays whose numbers of words range between $2385-5647$ words with a total of 24,215 words. Fish's data involves three essays whose total number of words is 23,991 . Table 2 below displays the data of study.

TABLE 2. Description of the analyzed data

\begin{tabular}{lll}
\hline Author & Text & No. of Words \\
\hline T.S. Eliot & The Sacred Wood- Blake & 1690 \\
& The Sacred Wood- Swinburne as a Poet & 1570 \\
The Sacred Wood- Philip Massinger & 4871 \\
The Sacred Wood- Rhetoric and Poetic Drama & 1837 \\
The Sacred Wood- Notes on the Blank Verse of Christopher & 1957 \\
& Marlowe & 2935 \\
The Sacred Wood- Dante & 4803 \\
The Sacred Wood- Ben Johnson & 1661 \\
The Sacred Wood- Euripides and Professor Murray & 3289 \\
Tradition and the Individual Talent & $\mathbf{2 4 , 6 1 3}$ \\
& Total & 5647 \\
& Letter to a Young Poet & 4130 \\
The Novels of E. M. Froster & 4568 \\
The Novels of Thomas Hardy & 3858 \\
Henry James: 3. The Letters of Henry James & 3560 \\
The Novels of George Meredith & 2360 \\
Jane Eyre and Wuthering Heights & \\
& Total & $\mathbf{2 4 , 1 2 3}$ \\
Interpreting the Variorum & 14796 \\
What It's Like To Read & 9195 \\
L' Allegro and Il Penseroso & $\mathbf{2 3 , 9 9 1}$ \\
Total & $\mathbf{7 2 , 7 2 7}$
\end{tabular}

The reason behind choosing those critics is that they were among the most influential figures of the theories of criticism they represent. Eliot is the most influential among all the modernists. Woolf, who is considered as the pioneer of the feminist literary criticism, is also a leading modernist writer. Her literary criticism reflects both modernism and feminism. As was mentioned earlier, Woolf recognized that writers of literary texts employ certain strategies to influence their readers. Thus, her writings stand between formalism and objectivism on the one hand, which neglect the role of the readers and their reactions and put emphasis only on the text itself and the reader response theory, on the other hand, which emphasizes the role of the readers and their reactions to the text. Fish is chosen because he is one of the leading members of the reader response theory.

The criteria behind choosing the texts mentioned in Table 2 above are popularity and availability. First, the researchers searched for the titles of critical essays that were written by the authors under investigation. These texts have been identified in the literature of critical 
essays as being among the most popular texts written by those writers. For example, "Interpreting the Variorum" is one of the important essays that reflects Fish's ability to settle critical disputes through employing his style of analysis that is characterized as being reader oriented (Mailloux, 1976). Another example is that "The Sacred Wood" contains a very wellknown critical essay in English, namely, "Tradition and the Individual Talent". This essay redirected and changed the statements about literature and literary works through reestablishing the meaning of tradition and how the artist is related to it (Teubner, 2017). Similarly, "A Letter to a Young Poet" by Virginia Woolf can be considered as one of her wellknown essays, since she expresses throughout it her points of view about modern poetry. The second reason behind analyzing these texts is that these are among the texts that are available online. After identifying the titles of the critical essays of each author, the researchers found out that not all of these texts are available online. Some of them were not very clear or incomplete. Thus, the texts that are the focus of attention in the literature and that are available online are those that were subject to analysis in this study.

\section{PROCEDURES OF DATA ANALYSIS}

The present research aims at investigating persuasion in literary criticism through studying the role of the reader in the different theories of criticism by examining the use of metadiscourse markers in critical essays being, according to Hyland (2005), one of the ways of achieving persuasion. To achieve this, Hyland's (2005) model of metadiscourse was applied to the corpus to identify the type and frequency of metadiscourse markers used in the genre of literary criticism and to check whether or not the different theories of criticism which the critics whose texts are analyzed in this study are reflected in the percentage, type and number of markers used. The distribution of each of the metadiscourse markers will be displayed, their communicative functions will be discussed and the results of the analysis of the three critics will be compared.

\section{RESULTS AND DISCUSSION}

\section{THE OVERALL FREQUENCY OF METADISCOURSE MARKERS}

As mentioned earlier, the number of the analyzed texts is 18, 9 by Eliot (24,613 words), 6 by Woolf (24,123 words) and 3 by Fish (23,991 words) forming a total of 72,727 words (cf. Table 2 above).

Results of the analysis showed that the total number of metadiscourse markers in the corpus is 3,994 as is clear in Table 3 below:

TABLE 3. Frequency and percentage of metadiscourse markers in the corpus

\begin{tabular}{lll}
\hline Type of Markers & Frequency & Percentage \\
\hline Interactive Markers & 1,989 & $47.96 \%$ \\
Interactional Markers & 2,158 & $52,04 \%$ \\
Total & 4,147 & $100 \%$ \\
\hline
\end{tabular}

The table above shows that in the corpus of 72,727 words, metadiscourse markers occurred 4,147 times forming $5.70 \%$. This means that in every 100 words of the corpus, 5 words are used as metadiscourse markers and in every 1000 words, 57 words indicate a metadiscursive function.

Regarding the distribution of the interactive and interactional metadiscourse markers in the analyzed texts, the analysis revealed that interactional markers were relied on more heavily 
with 2,158 times $(52,04 \%)$ when compared to interactive markers which are used 1,989 times $(47.96 \%)$.

As far as the frequency and distribution of metadiscourse markers among the three literary critics are concerned, it was found that interactional markers were used more than interactive markers by both Eliot and Woolf, whereas interactive markers were used more than interactional markers by Fish as shown in Table 4 below:

TABLE 4. Frequency and percentage of metadiscourse markers according to author

\begin{tabular}{llclc}
\hline Author & \multicolumn{2}{c}{ Interactive Markers } & \multicolumn{2}{c}{ Interactional Markers } \\
& No. & \% & No. & \% \\
\hline T.S. Eliot & 627 & $45.70 \%$ & 745 & $54.30 \%$ \\
Virginia Woolf & 599 & $41.80 \%$ & 834 & $58.20 \%$ \\
Stanley Fish & 763 & $56.86 \%$ & 579 & $43.14 \%$ \\
\hline
\end{tabular}

As shown from the table above, interactional markers were relied on more than interactive markers by Eliot and Woolf. Eliot used interactional markers 745 times forming $54.30 \%$ and used interactive markers 627 times forming 45.70\%; while Woolf used interactional markers 834 times forming $58.20 \%$ and used interactional markers 599 times forming $41.80 \%$. On the other hand, Fish used interactive markers more often 763 times forming $56.86 \%$ as compared to interactional markers which appeared 579 times forming $43.14 \%$.

When these results are compared to those of previous research on metadiscourse, one can see that there are points of similarities and points of differences. Previous research indicated that interactive markers are used more in written discourses (Hyland \& Tse, $2004 \&$ Khedri, 2014), whereas interactional markers are used more in spoken discourses (Cavalieri, 2011; Adel, 2012; Yipei \& Lingling, 2013; Malmstrom, 2014; Lee \& Subtirelu, 2015; Turiman et al., 2018; Mahmood \& Kasim, 2019; Mahmood \& Kasim, 2021). Even though the texts analyzed in this study are written, interactional markers are used more than interactive markers which can be attributed to the difference in the type of texts and genre (Adel, 2012, p. 93). Previous research involved analyzing academic texts, whereas the present study involves analyzing literary criticism texts. Some of the interactive markers, such as evidentials and endophoric markers were mainly used in academic discourse rather than literary discourse.

However, when the results of the current study are compared to those of previous research which involved analyzing literary texts, it is interesting to discover that the findings are similar that interactional markers are used more than interactive markers although the difference here is a little bit higher than in previous research (Ahangari \& Kazemi, 2014; Aljazrawi \& Aljazrawi, 2019).

\section{INTERACTIVE MARKERS}

As is shown in table (4) above, the number of occurrences of interactive markers is 1,989 . This number is unequally divided among four of the interactive markers which are transitions, frame markers, code glosses and evidentials as shown in Table 5 below:

TABLE 5. The frequency and percentage of interactive markers in the corpus

\begin{tabular}{lll}
\hline Types of Markers & Number of Markers & Percentage of Markers \\
\hline Transitions & 1,730 & $86.98 \%$ \\
Frame Markers & 217 & $10.91 \%$ \\
Code Glosses & 29 & $1.46 \%$ \\
Endophoric Markers & 0 & $0 \%$ \\
Evidentials & 13 & $0.65 \%$ \\
Total & 1,989 & $100 \%$ \\
\hline
\end{tabular}


It is obvious from the table above that transitions is the most frequently used interactive marker in that it appeared 1,730 times in the corpus forming $86.98 \%$ of the total number of interactive markers. It's important to note that in almost all of the previous metadiscourse studies whether analyzing spoken or written, literary or non-literary texts, transitions is the most widely used metadiscourse marker. This may be attributed to the fact that transition markers help writers make their texts cohesive and assist readers to understand the connections between ideas. In addition, by the use of transitions, writers are able to make their texts persuasive by means of the rational appeal (logos), since transition markers usually connect the steps of an argument.

In terms of function, transition markers are classified into Addition, Comparison and Consequence. Addition markers are the most frequently used among the other transition markers and are mainly realized through the use of 'and'. Comparison is the second most frequently used subcategory of transition markers and is mainly realized by the use of 'but', whereas Consequence is the least used subcategory which is realized by the use of 'therefore'.

The following examples of transitions markers are taken from the data:

1. A novelist, we reflect, is bound to build up his structure with much very perishable material which begins by lending it reality and ends by cumbering it with rubbish.

2. It is of course not the actual information acquired, but the conformity which the accumulation of knowledge is apt to impose, that is harmful.

3. The distinction underlying this between the experience of a poem and what one might say about it subsequently - will not hold because the characterization of the experience follows from a set of assumptions (about what one does when reading, about the inability of readers to withhold response, and so on) and is therefore itself an interpretation.

Frame markers are the second most frequently used of interactive marker. Those markers appeared 217 times in the data forming 10.91\% of the total number of interactive markers. Those markers performed the function of sequencing the arguments within a text rather than events in time. Thus, they were used by writers to achieve clarity of discourse and persuade readers through the rational appeal (logos). The most frequently used frame marker is 'then' followed by 'first'. In addition, there are other frame markers that appeared in the corpus, such as 'finally', 'before' and 'after'.

The following examples are taken from the data:

1. I then identified that base with the experience of a work, and argued that formalist criticism, because it is spatial rather than temporal in its emphasis, either ignored or suppressed what is really happening in the act of reading.

2. First of all it is "pure," that is, absolute, in its claims: three hundred years of L'AllegroIl Penseroso criticism are declared to have been in error because professional readers have insisted on interpreting a poem that is designed precisely to relieve us from the care and attention that interpretation requires.

3. Not only are these activities sustained, but they have a single object, the precise elucidation of the nature of melancholy; and this continues to be true when the focus of the poem shifts to the speaker, for in his wanderings he repeatedly acts out the sequence that joins the other figures we have encountered, Three times he retires from the light 
of day into an enclosure: first in some "removed place" (79) where light is taught to counterfeit a Gloom, later in twilight groves (133) that have been sought specifically to escape the Sun's flaring beams, and finally in the "Cloister's pale" (156) where the light streaming through the windows is deemed religious because it is "dim."

4. But before I begin, I must own up to those defects, both natural and acquired, which, as you will find, distort and invalidate all that I have to say about poetry.

5. But after a survey of those explanations, we read that "all that is certain is that the shepherds were sitting" (p. 288); anything else, "the reader must decide for himself".

Code glosses occupied the third position among interactive markers in terms of occurrence 29 times forming $1.46 \%$ of the total number of interactive markers. Its function is to help the reader understand the writer's intended meaning by supplying additional information through explanation, elaboration and rephrasing. Code glosses are also one of the means that writers use to persuade their readers through the rational appeal (logos) which makes readers believe in something through following and accepting a particular argument. 'In other words' is the most frequently used of the code glosses markers followed by 'for example' and finally comes 'namely'.

The following examples are taken from the data:

1. In other words, we know and understand the quality of their untroubled (careless) joy because it is precisely reflected in the absence of any pressure on us to make more of their landscape than its surfaces present.

2. Consider, for example, the concluding lines of another of Milton's sonnets, "Avenge O Lord thy slaughtered saints."

3. And if M. Valéry is in error in his complete exorcism of "philosophy," perhaps the basis of the error is his apparently commendatory interpretation of the effort of the modern poet, namely, that the latter endeavors "to produce in us a state."

The least frequently occurring interactive marker is evidentials. As shown in Table 5 above, evidentials markers were used only 13 times in the data forming $0.65 \%$ of the total number of metadiscourse markers. Evidentials are used to refer to ideas from other sources which could be, in some genres, a reference to a reliable source. In academic writing, on the other hand, they are used to support arguments by referring to a related literature (Hyland, 2005). Thus, it is possible to conclude that evidentials are mainly found in academic discourse and other genre types and this justifies the limited number of occurrences of these markers in the data. Almost all of the instances of evidentials are realized by 'said' and there was only one instance of 'according to'.

The following examples are taken from the data:

1. There is of course no warrant for these emendations, and in 1791 Thomas Warton had the grace and honesty to admit as much. "I have," he said, "introduced the turned commas both in the question and answer not from any authority, but because they seem absolutely necessary to the sense.' 
2. Wuthering Heights is a more difficult book to understand than Jane Eyre, because Emily was a greater poet than Charlotte. When Charlotte wrote she said with eloquence and splendour and passion "I love", "I hate", "I suffer".

It is worth noting that not even one instance of endophoric markers has appeared in the data. The function of those markers is to refer to previous or coming parts of a text and thus, support the reader's comprehension of a text. They are mainly characteristics of academic texts.

\section{INTERACTIONAL MARKERS}

As mentioned and shown in Table 3 above, interactional markers occurred 2,158 times in the corpus forming $52.04 \%$ of the total number of metadiscourse markers. Table 6 below shows that among the five types of interactional markers, self-mention is the most frequently used. This marker occurred 1,085 times in the data forming $50.28 \%$ of the total number of interactional markers and it is achieved mainly through the use of 'we', 'I', 'our', 'me' and 'mine' respectively. Through this marker, text authors indicated their presence in their texts using possessive adjectives and first person pronouns for the purpose of expressing their attitudes towards their own arguments, their community and readers (Hyland, 2005). Writers managed to make their texts persuasive through stimulating an ethos. Thus, the means of achieving persuasion was the writer's credibility and by trusting the writer's judgment and goodwill, readers were being convinced of something. The authors of the critical essays under study have mainly used the pronoun 'we' to indulge their readers in their texts.

TABLE 6. The frequency and percentage of interactional markers in the corpus

\begin{tabular}{lll}
\hline Types of Markers & Number of Markers & Percentage of Markers \\
\hline Hedges & 732 & $33.92 \%$ \\
Boosters & 58 & $2.69 \%$ \\
Attitude Markers & 17 & $0.79 \%$ \\
Engagement Markers & 266 & $12.32 \%$ \\
Self-mention & 1,085 & $50.28 \%$ \\
Total & 2,158 & $100 \%$ \\
\hline
\end{tabular}

The following examples are taken from the data:

1. When we say that the death of Thomas Hardy leaves English fiction without a leader, we mean that there is no other writer whose supremacy would be generally accepted, none to whom it seems so fitting and natural to pay homage.

2. What $I$ did not then see is that the moment that disappears in a formalist analysis is the moment that has been made to appear in another kind of analysis, the kind of analysis $\boldsymbol{I}$ was urging in this essay.

3. Our appreciation may be intense, but our curiosity is even greater. Does the new fragment add anything to what went before? Does it carry out our theory of the author's talent, or must we alter our forecast? Such questions ruffle what should be the smooth surface of our criticism and make it full of argument and interrogation.

Hedges marker is the next most frequently occurring interactional marker with 732 instances forming $33.92 \%$ of the total number of interactional markers. Expressions, such as may/might, can/could or would were used by writers in order to express opinions instead of facts and showed that a particular statement was dependent on its reasonings rather than on 
certain knowledge. Epistemic verbs, such as 'seems' and 'possible' and epistemic adverbs like 'whatever' and 'probably' were also used in the data. Through the use of hedges, writers achieved persuasion, since they aimed at influencing their readers to make them adopt their viewpoints or opinions or their way of thinking or behaving (Halmari and Vritanen, 2005).

The following examples are taken from the data:

1. Herbert F. West, Jr., admits that such an accident of misplacement is "possible" and that Graves' emendation "does little apparent danger to the text*' and even seems to "smooth over some difficult spots.

2. It would be possible to continue with this profile of the optimal reader, but I would not get very far before someone would point out that what I am really describing is the intended reader, the reader whose education, opinions, concerns, linguistic competences, and so on make him capable of having the experience.

3. Whatever one may think of this interpretive program, its success and ease of execution are attested to by centuries of Christian exegesis.

4. In 1958 Robert Graves went so far as to suggest that in the course of composing L'Allegro Milton misplaced sixteen lines, probably over the weekend.

Engagement markers occupy the third position in terms of frequency of occurrence as shown in Table 6 above. Those markers were used 266 times forming $12.32 \%$ of the total number of interactional markers. Engagement markers were used by writers in order to engage their readers in the text through the use of verbs like, 'consider', 'note' and directives. The analysis showed that directives, namely, obligation modals (must, should, have to and need) were the most frequently used type of engagement markers in the data.

The following examples are taken from the data:

1. It is this awareness that I am claiming for myself, although in doing so I must give up the claims implicitly made in the first part of this essay.

2. (1 should add that the notions "pastoral" and "Milton" are also interpretations; that is, they do not stand for a set of indisputable, objective facts; if they did, a great many books would not now be getting written).

3. In fact, however, the history I dismiss (the critical history of the poem) is responsible for what I have to say and for the force with which I can say it.

The fourth interactional marker in terms of frequency of occurrence, as Table 6 above shows, is boosters. Boosters appeared 58 times forming $2.69 \%$ of the total number of interactional markers. Writers used boosters for the purpose of reflecting their certainty regarding what they say. Through the use of boosters and hedges, writers indicated their commitment and respect to their texts and readers respectively. Boosters were realized in the data mainly through the use of 'obviously', 'clearly' and 'firmly' in addition to other expressions which reflect certainty.

The following examples are taken from the data:

1. Obviously, that attention is not only consecutive but strenuous.

2. Clearly therefore you have it in you to deal with a vast variety of subjects; it is only a temporary necessity that has shut you up in one room, alone, by yourself. 
3. All of these readings hang on the word "while" in line 49, but since "while" is less timespecific than other temporal adverbs, it does not firmly call for any one of these and, more to the point, it functions equally well, that is, equally loosely, in all of them.

The least of the interactional markers in terms of frequency is attitude markers which occurred 17 times in the data forming $0.79 \%$ of the total number of interactional markers as Table 6 above shows. The writers used these markers when they were concerned with expressing surprise, importance, agreement, obligation, rather than indicating the reliability of the information. These markers enabled writers to persuade their readers through affecting their emotions by using the emotional appeal (pathos). These markers were realized by the use of adjectives 'remarkable', 'appropriate', attitude verbs 'prefer' and sentence adverbs 'fortunately' and 'surprisingly'.

The following examples are taken from the data:

1. I shall not comment on this remarkable passage, nor on its historical assumptions, except to point out that in it every appearance the word 'Word' is capitalized (as it is in the French); perhaps there is something in that "magic vacuum" after all. Let US See.

2. Mr. Peabody, and his like - who much prefer death to life and are even now intoning the sacred and comfortable words, Keats is dead, Shelley is dead, Byron is dead. But it is late.

3. It is significant that Richard and Lucy, Harry and Ottilia, Clara and Vernon, Beauchamp and Renée are presented in carefully appropriate surroundings--on board a yacht, under a flowering cherry tree, upon some river-bank, so that the landscape always makes part of the emotion.

4. MASSINGER has been more fortunately and more fairly judged than several of his greater contemporaries.

\section{THE FREQUENCY OF METADISCOURSE MARKERS ACCORDING TO AUTHOR AND THEORY OF CRITICISM}

It has been mentioned above that the data selected for analysis belong to three authors who represent three different theories of criticism. This study also looks at how the theory they adopt affects their texts and the way they make their texts persuasive. In terms of the frequency and percentage of metadiscourse markers used, the analysis revealed that the highest number of metadiscourse markers appeared in the critical essays written by Virginia Woolf followed by T.S. Eliot and Stanley Fish as shown in Table 7 below.

TABLE 7. Metadiscourse markers according to author

\begin{tabular}{|c|c|c|c|c|c|c|}
\hline \multirow[t]{2}{*}{ Author } & \multicolumn{2}{|c|}{ Interactive Markers } & \multicolumn{2}{|c|}{ Interactional Markers } & \multirow{2}{*}{$\begin{array}{l}\text { Total } \\
\text { No. }\end{array}$} & \multirow{2}{*}{$\begin{array}{l}\text { Percentage } \\
\%\end{array}$} \\
\hline & No. & $\%$ & No. & $\%$ & & \\
\hline T.S. Eliot & 627 & $45.70 \%$ & 745 & $54.30 \%$ & 1372 & $33.09 \%$ \\
\hline Virginia Woolf & 599 & $41.80 \%$ & 834 & $58.20 \%$ & 1433 & $34.55 \%$ \\
\hline Stanley Fish & 763 & $56.86 \%$ & 579 & $43.14 \%$ & 1342 & $32.36 \%$ \\
\hline Total & 1,989 & & 2,158 & & 4,147 & $100 \%$ \\
\hline
\end{tabular}


As shown in the table above, metadiscourse markers occurred more frequently in the critical essays of Virginia Woolf, being used 1433 times forming 34.55\% of the total number of metadiscourse markers in the data. In the critical essays of T.S. Eliot, metadiscourse markers appeared 1372 times forming 33.09\% of the total number while the critical essays of Stanley Fish, metadiscourse occurred 1342 times forming $32.36 \%$ of the total number of markers used. It is worth mentioning that these differences are not very significant.

In terms of the frequency of interactive and interactional markers, the critical essays by T.S. Eliot, who is considered as the most influential among all the modernists, contained a higher number of interactional markers with 745 instances forming $54.30 \%$ compared to interactive markers with 627 instances forming 45.70\%. Although T.S. Eliot is one of the most influential modernists who believes that criticism should concentrate on the text itself and its formal aspects rather than its effect on the reader, his critical essays were characterized by a frequent use of metadiscourse markers whose function was to assist in guiding the reader through the text (interactive markers) and to involve the reader in the text (interactional markers). Even more, his critical essays were characterized by using interactional markers to achieve persuasion in his writings. When we analyze the frequency and percentage of interactive markers used, we could see that the most frequently used interactive marker in Eliot's critical essays is transitions being used 593 times forming $94.58 \%$ of the total number of interactive markers followed by frame markers 23 times forming 3.67\%, code glosses 7 times forming $1.11 \%$ and finally evidentials 4 times forming $0.64 \%$ of the total number of interactive markers.

As for the interactional markers, it is obvious from the table below that the most frequently used interactional marker is self-mention 326 times forming $43.76 \%$ of the total number of interactional markers followed by hedges 288 instances $(38.66 \%)$, engagement markers 103 instances $(13.82 \%)$, boosters 21 instances $(92.82 \%)$ and finally attitude markers 7 times forming $0.94 \%$ of the total number of interactional markers.

TABLE 8. Metadiscourse markers in T.S. Eliot critical essays

\begin{tabular}{llllll}
\hline Interactive Markers & No. & Percentage & Interactional Markers & No. & Percentage \\
\hline Transitions & 593 & $94.58 \%$ & Hedges & 288 & $38.66 \%$ \\
Frame markers & 23 & $3.67 \%$ & Boosters & 21 & $2.82 \%$ \\
Endophoric markers & 0 & $0 \%$ & Attitude markers & 7 & $0.94 \%$ \\
Evidentials & 4 & $0.64 \%$ & Engagement markers & 103 & $13.82 \%$ \\
Code glosses & 7 & $1.11 \%$ & Self-mention & 326 & $43.76 \%$ \\
Total & $\mathbf{6 2 7}$ & $45.70 \%$ & Total & $\mathbf{7 4 5}$ & $54.30 \%$ \\
\hline
\end{tabular}

As for the writings of Virginia Woolf, whose literary criticism reflects modernism and feminism (Habib, 2005:682), the analysis revealed that interactional markers are used 834 instances forming $58.20 \%$ as compared to interactive markers with 599 instances forming $41.80 \%$. Thus, it is evident that Woolf is using metadiscourse markers for the purpose of achieving certain effects among her readers. Like T.S. Eliot, Woolf's critical essays are characterized by the use of interactional markers more than interactive markers. In addition, as in T.S. Eliot's critical essays, the most frequently used interactional marker is self-mention 445 times forming $53.36 \%$ followed by hedges 255 times $30.57 \%$, engagement markers 111 $(13.31 \%)$, boosters $19(2.28 \%)$ and finally attitude markers 4 times forming $0.48 \%$ of the total number of interactional markers. 
TABLE 9. Metadiscourse markers in Virginia Woolf critical essays

\begin{tabular}{llllll}
\hline Interactive Markers & No. & Percentage & Interactional Markers & No. & Percentage \\
\hline Transitions & 526 & $87.81 \%$ & Hedges & 255 & $30.57 \%$ \\
Frame markers & 66 & $11.02 \%$ & Boosters & 19 & $2.28 \%$ \\
Endophoric markers & 0 & $0 \%$ & Attitude markers & 4 & $0.48 \%$ \\
Evidentials & 3 & $0.50 \%$ & Engagement markers & 111 & $13.31 \%$ \\
Code glosses & 4 & $0.67 \%$ & Self-mention & 445 & $53.36 \%$ \\
Total & $\mathbf{5 9 9}$ & $41.80 \%$ & Total & $\mathbf{8 3 4}$ & $58.20 \%$ \\
\hline
\end{tabular}

For Stanley Fish, who adopts the reader-response theory which emphasizes the role of the readers of literary texts, the findings revealed that interactive markers were used more frequently than interactional markers. According to the reader-response theory, the identification of literary works can be created by the existence of both the reader and the text (Iser, 1974 p. 274 as cited in Habib, 2005, p. 735). Thus, according to this theory, it is the reader rather than the text which is the focus of criticism (Iser, 1974, p. 274 as cited in Habib, 2005 , p. 735). When comparing the number of instances of metadiscourse markers in the critical essays of Fish, one can find that the number was the least among the three authors although the difference is not that significant (Table 7 above). However, the differences between Fish's critical essays and those of Eliot and Woolf lie in the types of interactive and interactional markers used.

As Table 10 below shows, interactive markers are used more than interactional markers with 763 instances forming $56.86 \%$ of the total number of metadiscourse markers in Fish's critical essays. Interactional markers occurred 579 times forming $43.14 \%$ of the total number of metadiscourse markers used. Transitions were the most frequently used marker with 611 instances forming $80.09 \%$. This is similar to what was identified in the critical essays of Eliot and Woolf where transition markers were the highest in terms of occurrence among the other interactive markers. Frame markers occupy the second position in terms of occurrence being used 128 forming $16.76 \%$. This percentage is the highest when compared to those of frame markers in the critical essays of Eliot and Woolf. Code glosses come next in terms of occurrence with 18 instances forming $2.36 \%$ and evidentials with 6 instances forming $0.79 \%$ of the total number of interactive markers.

As for interactional markers, self-mention is the most frequently used marker with 314 instances forming $54.23 \%$ followed by hedges 189 (32.64\%), engagement markers $52(8.98 \%)$, boosters $18(3.10 \%)$ and finally attitude markers with only 6 instances forming $1.04 \%$ of the total number of interactional markers.

TABLE 10. Metadiscourse markers in Stanley Fish critical essays

\begin{tabular}{llllll}
\hline Interactive Markers & No. & Percentage & Interactional Markers & No. & Percentage \\
\hline Transitions & 611 & $80.09 \%$ & Hedges & 189 & $32.64 \%$ \\
Frame markers & 128 & $16.76 \%$ & Boosters & 18 & $3.10 \%$ \\
Endophoric markers & 0 & $0 \%$ & Attitude markers & 6 & $1.04 \%$ \\
Evidentials & 6 & $0.79 \%$ & Engagement markers & 52 & $8.98 \%$ \\
Code glosses & 18 & $2.36 \%$ & Self-mention & 314 & $54.23 \%$ \\
Total & $\mathbf{7 6 3}$ & $56.86 \%$ & Total & $\mathbf{5 7 9}$ & $43.14 \%$ \\
\hline
\end{tabular}

Thus, it is clear from the findings that the theory of criticism that each of the authors adopts does not affect much of their use of metadiscourse markers as far as the number and percentage are concerned. The three authors made use of those markers although with slight differences in number and percentage. However, as far as the type of markers used is concerned, it was found out that both Eliot and Woolf used interactional markers with the aim of involving the reader, whereas Fish used interactive markers to assist in guiding the readers. 
While most of the instances of interactive markers in Eliot's and Woolf's critical essays were realized by transition markers, Fish's critical essays were characterized by the use of frame markers and code glosses. On the other hand, when moving to interactional markers, we can see that all the three authors used self-mention more than other interactional markers followed by hedges, engagement markers, boosters and attitude markers. Thus, it is possible to conclude that the theory of criticism that the three authors adopt does not place much influence in their use of metadiscourse markers. The only difference is that while Fish chose to persuade his readers by depending more on the rational appeal (logos), Eliot and Woolf chose to persuade their readers by depending more on the credibility appeal (ethos) and the affective appeal (pathos).

\section{CONCLUSION}

The current research examined the frequency and distribution of metadiscourse markers used by these literary critics, namely, T.S. Eliot, Virginia Woolf and Stanley Fish and how the different theories of criticism they adopt affect their writing. The findings indicated that the literary critics under investigation used metadiscourse markers in their critical essays to achieve coherence, cohesion and also persuasion in their texts.

The small difference in the number and percentage of interactive and interactional markers reflects that both types are important in literary criticism texts. Moreover, the fact that the result of this study which examined literary criticism texts regarding the distribution of interactive and interactional markers was similar to previous studies which also examined other types of literary texts, such as novels and short stories and also academic texts. Interactive markers are used by literary critics to create coherent texts and to help their readers understand their intended meaning. In addition, by using such markers, literary critics manage to persuade their readers by using the rational appeals (logos).

On the other hand, to express their attitudes, opinions and their commitment to their texts, literary critics employ interactional markers. In addition, they make use of those markers in order to engage their readers in the text for the purpose of making their texts persuasive. Thus, they manage to convince their readers of their opinions and attitudes by means of the credibility appeal (ethos) and the affective appeal (pathos).

The non-significant differences in the number and percentages of metadiscourse markers used by the three literary critics who adopt different critical theories indicated that the use of those markers did not affect the critical theory that the literary critic adopts. However, some of them prefer to rely more on the rational appeal (logos) to persuade their readers and make their texts persuasive, and others prefer to rely more on the credibility appeal (ethos) and the affective appeal (pathos). The study findings enabled authors of critical essays to reflect their theories into their essays by relying more on the linguistic features that reflect the theory they adopt. This study contributes significantly to the genre of critical essays through identifying the suitable features to be used in producing texts that are more convincing and coherent and achieving maximum effect on readers. 


\section{REFERENCES}

Abdulmughni, S. A. S. (2019). Stylistics, literary criticism, linguistics and discourse analysis. International Journal of English Linguistics. 9(2), 412.

Adel, A. (2006). Metadiscourse in L1 and L2 English. Amsterdam: John Benjamins Publishing Co.

Adel, A. (2012). "What I Want You to Remember Is...": Audience orientation in monologic academic discourse. English Text Construction. 5(1), 101-127.

Ahangari, S. \& Kazemi, M. (2014). A content analysis of 'Alice in Wonderland' regarding metadiscourse elements. International Journal of Applied Linguistics and English Literature. 3(3), 10-18. https://doi.org/10.7575/aiac.ijalel.v.3n.3p.10

Aljazrawi, D \& Aljazrawi, Z (2019). The use of metadiscourse: An analysis of interactive and interactional markers in English short stories as a type of literary genre. International Journal of Applied Linguistics \& English Literature. 8(3), 66-77.

Baktır, H. (2018). Metinde anlam: Okur - tepkisi eleştiri kuramı. Temaşa Erciyes Üniversitesi Felsefe Bölümü Dergisi. 8, 97-105.

Bäcklund, I. (1998). Metatext in professional writing: A contrastive study of English, German and Swedish. Texts in European writing communities 3. Uppsala universitet. TeFa $\mathrm{nr}$ 25.

Beckson, K., \& Ganz, A. (1989). Literary Terms: A Dictionary: $3^{\text {rd }}$ ed. New York: Noonday Press.

Bressler, Charles E. (2002). Literary criticism: An Introduction to Theory and practice. New Jersey: Upper saddle River.

Bunton, D. (1999). The use of higher level metatext in Ph.D theses. English for Specific Purpose. 18, 41-56 https://doi.org/10.1016/S0889-4906(98)00022-2

Cavalieri, S. (2011). The role of metadiscourse in counsels' questions. Exploring courtroom discourse: The language of power and control, 79-110.

Crismore, A. (1989). Talking with Readers: Metadiscourse as rhetorical act. New York: Peter Lang. https://books.google.com/books?id=BXsFAQAAIAAJ

Crismore, A., Markkanen, R. \& Steffensen, M.S. (1993). Metadiscourse in persuasive writing: A study of texts written by American and Finnish University students. Written Communication. 10(1), 39-71. https://doi.org/10.1177/0741088393010001002.

Dahl, T. (2004). Textual metadiscourse in research articles: A marker of national culture or of academic discipline? Journal of Pragmatics. 36(10), 1807-1825. https://doi.org/10.1016/j.pragma.2004.05.004

Dainton, M. (2005). Applying Communication Theory for Professional Life: A Practical Introduction. Thousand Oaks, Calif: SAGU Publications.

Eagleton, T. (2001). Literary Theory: An Introduction (2 $2^{\text {nd }}$ ed.). Minnesota; The University of Minnesota Press.

Garsten, B. (2006). Saving Persuasion: A Defence of Rhetoric and Judgment. Cambridge: Harvard University Press.

Griffith, K. (2002). Writing Essays about Literature. (A Guide and Style Sheet). Thompson Heinle Incorporation.

Habib, M.A.R. (2005). Modern Literary Criticism and Theory. A History. Oxford: Blackwell Publishing Ltd.

Halmari, H. \& Vritanen, T. (2005). Persuasion across Genres: A Linguistic Approach. Amsterdam/Philadelphia: John Benjamins Publishing Company.

Harris, W. V. (1996). The discourse of literary criticism and theory. Social Epistemology: A Journal of Knowledge, Culture and Policy. . 10(1), 75-88.. 
Hyland, K. (1998). Exploring corporate rhetoric: Metadiscourse in the CEO's letter. Journal of Business Communication. 35(2), 224-245. https://doi.org/10.1177/002194369803500203

Hyland, K. (2005). Metadiscourse: Exploring Interaction in Writing. London: Continuum. https://books.google.com/books?id=kyztT1czUfMC

Hyland, K. \& Tse, p. (2004). Metadiscourse in academic writing: A reappraisal. Applied Linguistics. 25(2), 262-177. https://doi.org/10.1093/applin/25.2.156

Iser, W. (1974). The Implied Reader: Patterns of Communication in Prose Fiction from Bunyan to Beckett. Johns Hopkins University Press.

Khedri, M. (2014). A cross-disciplinary exploration of metadiscourse in experimental research articles. Unpublished $\mathrm{PhD}$ thesis, Universiti Putra Malaysia, Malaysia.

Larson, C. (2010). Persuasion: Reception and Responsibility. Belmont: Wadsworth, Cengage Learning.

Lee, J.J. \& Subtirelu, N.C. (2015). Metadiscourse in the classroom: A comparative analysis of EPA lessons and university lectures. English for Specific Purpose. 37(1), 52-62. https://doi.org/10.1016/j.esp.2014.06.005

Lynn, S. (1998). Texts and Contexts: Writing about Literature with Critical Theory. New York: Longman.

Mahmood, I. I., \& Kasim, Z. M. (2019). Interpersonal metadiscursive features in contemporary Islamic Friday sermon. 3L: The Southeast Asian Journal of English Language Studies. $25(1), 85-99$.

Mahmood, I. I., \& Kasim, Z. M. (2021). Metadiscourse Resources across Themes of Islamic Friday Sermon. GEMA Online ${ }^{\circledR}$ Journal of Language Studies, 21(1), 45-60.

Mailloux, Steven. (1976). Stanley Fish's “Interpreting the Variorum": Advance or Retreat? Critical Inquiry. 3(1), 183-190. The University of Chicago Press.

Makaryk, I. (1993). Encyclopedia of Contemporary Literary Theory: Approaches, Scholars, Terms. University of Toronto Press.

Malaskova, M. (2014). Hedging in Academic Discourse: A Comprehensive Analysis of Applied Linguistics and Literary Criticism Research Articles. PhD Dissertation. Masaryk University.

Malmstrom, H. (2014). Engaging the congregation: The place of metadiscourse in contemporary preaching, Applied Linguistics. 37(4), 561-582. https://doi.org/10.1093/applin/amu052

Mao, L. R. (1993). I conclude not: Toward a pragmatic account of metadiscourse. Rhetoric Review. 11(2), 265-289. https://doi.org/10.1080/07350199309389006

Mauranen, A. (1993). Cultural Differences in Academic Rhetoric: A Textlinguistic Study. Frankfurt am Main: Peter Lang.

Miller, G. R. (1980). On being persuaded: Some basic distinctions. In M. E. Roloff and G. R. Miller (Eds.), Persuasion: new directions and theory and research (Sage annual reviews of communication research. 8, (PP. 1128). Beverly Hills, CA: Sage.

O'keefe, Daniel, J. (1990). Persuasion: Theory and Research. Newbury Park, CA: Sage Publications, Inc.

Ransom, J. C. (1941). The New Criticism. Folcroft, Pa.: Folcroft Library Editions.

Schiffrin, D. (1980). Metatalk: Organizational and evaluative brackets in discourse". Sociological Inquiry: Language and Social Interaction. 50(3-4), 199-236. https://doi.org/10.1111/j.1475-682X.1980.tb00021.x .

Simons, H. W. (1976). Persuasion: Understanding, Practice, and Analysis. New York: Newbery Award Records, Inc.

Stern, B. B. (1989). Literary criticism and consumer research: Overview and illustrative analysis. The Journal of Consumer Research. 16, (322-334). 
Telenius, J. (1994). Guiding the reader: The use of metatext in master's theses written in English. Helsingin School of Economics and Business Administration.

Teubner, R. (2017). An Analysis of T.S Eliot's The Sacred Wood: Essays on Poetry and Criticism. Macat Library.

Turiman, S., Abdullah, N., \& Noor, N. M. (2018). Spoken metadiscourse in Malaysian ESL job interviews. GEMA Online ${ }^{\circledR}$ Journal of Language Studies. 18(3).

Vande Kopple, W. J. (1985). Some exploratory discourse on metadiscourse, College Composition and Communication. 36(1), 82-93.

Vande Kopple, W. \& Shoemaker, A. (1988). Metadiscourse and the recall of modality markers. Visible Language, 22(2), 233.

Williams, J. (1981). Style: Ten Lessons in Clarity and Grace. Glenview, Illinois: Scott: Foresman and Company.

Yipei, N. \& Lingling, L. (2013). Investigating the interpersonal and textual meanings of Steve Jobs Stanford speech in terms of Hyland's metadiscourse theory. International Journal of Language and Linguistics. 1(4), 90-96.

\begin{abstract}
ABOUT THE AUTHORS
Dunya AlJazrawi, $\mathrm{PhD}$, is an associate professor of English at Kingdom University in Bahrain. She was a teaching staff member in the Department of English, College of Arts/ University of Baghdad. She also worked as the director of the English Language Development Center at Gulf University in Bahrain.

Zeena AlJazrawi, $\mathrm{PhD}$, is an assistant Prof of English at Kingdom University in Bahrain. She worked as a lecturer in the Department of English, College of Arts/ University of Baghdad. She also worked as a teaching staff member in the English Language Development Centre at Gulf University in Bahrain.
\end{abstract}

